\title{
Study of aquatic flora of selected ponds of Gandhinagar, Gujarat
}

\author{
Madhavi Singh, Bharat Maitreya \\ Department of Botany, Bioinformatics, Climate Change Impacts Management, University School of Sciences, \\ Ahmedabad, Gujarat, India
}

\section{ABSTRACT}

Article Info

Volume 8, Issue 3

Page Number : 48-51

Publication Issue

May-June-2021

Article History

Accepted : 01 May 2021

Published : 05 May 2021
The aquatic plants of three ponds located in Gandhinagar district, Gujarat were studied for a period of seven months. Altogether 24 genera of aquatic and marshy plants were identified in the present investigation. The physicochemical characteristics of pond water to be altered due to these aquatic plants. Keywords : Aquatic, Plants, Ponds, Gandhinagar.

\section{INTRODUCTION}

Inland wetlands, lakes, and ponds are important environmental resources that store excess floodwaters, improve water quality, provide habitat for fish and wildlife, and recharge groundwater aquifers (Ozesmi and Bauer, 2002). Aquatic plants have been recognized as important components of these freshwater ecosystems (Olmanson et al., 2002). Emergent aquatic macrophytes provide shade, cover, and help to maintain cooler water temperatures necessary for fish and other aquatic organisms (Jakubauskas et al., 2000; Vis et al., 2003).

Gandhinagar is capital city of Gujarat. There are several ponds in and around Gandhinagar. Various urban and village ponds of Gandhinagar were surveyed during the study period, but only three ponds were selected. The present study was carried out for a period of seven months from September
2017 to March 2018. Gandhinagar has a tropical wet and dry climate. The climate is generally dry and hot outside of the monsoon season. The weather is hot to severely hot from March to June when the maximum temperature stays in the range of 36 to $42^{\circ} \mathrm{C}$ (97 to $108^{\circ} \mathrm{F}$ ), and the minimum in the range of 19 to $27^{\circ} \mathrm{C}$ (66 to $81^{\circ} \mathrm{F}$ ). Almost $90 \%$ of the rainfall occurs during monsoon season, with a few exceptions.

The present investigation was aimed to study the aquatic plants of three ponds of Gandhinagar district, Gujarat.

\section{Material and Methods}

Samples were collected and identified using the morphological key characters of the plants and it was compared with the plant floras. We have used various volumes of floras like flora of Gujarat (Shah 1978), Flora of Maharashtra (Singh 2001) and other digital 
floras for more information of the plants. Synonyms and accepted name were checked and confirmed from experts and authentic institutions. Voucher preparation was done by drying the specimen using herbarium press. The voucher was placed in blotting paper and pressed in herbarium press. Specimen were allowed to dry at room temperature and blotters were regularly changed. The specimen was treated with $2 \%$ $\mathrm{HgCl} 2$ solution to protect fungal and insect contaminations. After drying the specimen, it would be mounted on standard herbarium sheet by knitting method. When the herbarium was prepared, next step was to label the herbarium. Labelling should include: name of the institution in which the specimen is deposited, local name, accepted botanical name with taxonomy authority, family, GPS/location, name of the collectors, collection date, identifiers, taxon ID, habitat and description. In last, herbarium sheets were covered with plastic bag and stored in cool, dry place and minimize exposure to UV rays.

\section{Results and Discussion}

In this research, it is found that all the three ponds have distribution of hydrophytes and marshy plants. Pond 1 is rich in species, when compared to other ponds. A total of 25 plant species were recorded in the three ponds during the study period. It is represented in the form of table-1. Pond 2 and 3 get almost dry by end of January month and then grow up the characteristic vegetation of cold season. Most of the plants disappear with the beginning of hot season. However, when the soil is completely dry during summer very few plants can survive until the shower of rain in monsoon season. Some plants occur in pure or mixed patches along the dry edge of ponds. Depending upon the seasonal changes the plants appear or disappear in their occurrence area.

Table -1. Distribution of Hydrophytes and Marshy plant species in study area

\begin{tabular}{|l|l|l|l|l|l|}
\hline Sr. No. & $\begin{array}{l}\text { Hydrophytes and marshy plant } \\
\text { species }\end{array}$ & Family & $\begin{array}{l}\text { Pond } \\
1\end{array}$ & $\begin{array}{l}\text { Pond } \\
2\end{array}$ & Pond 3 \\
\hline 1. & Abutilon indicum (L.) Sw. & Malvaceae & - & + & - \\
\hline 2 & Alternanthera sessilis (L.) Dc. & Amaranthaceae & + & + & + \\
\hline 3 & Ammania baccifera L. & Lythraceae & + & + & - \\
\hline 4 & Argemone mexicana L. & Papaveraceae & + & + & + \\
\hline 5 & Bacopa monnieri (L.) Pennell & Scrophulariaceae & + & + & - \\
\hline 6 & Celosia argentea L. & Amaranthaceae & - & + & + \\
\hline 7 & Chloris barbata Sw. & Poaceae & + & + & + \\
\hline 8 & Cleome viscosa Linn & Capparaceae & + & + & + \\
\hline 9 & Clitoria ternatea L. & Fabaceae & + & + & + \\
\hline
\end{tabular}


Madhavi Singh et al Int J Sci Res Sci \& Technol. May-June-2021, 8 (3) : 48-51

\begin{tabular}{|c|c|c|c|c|c|}
\hline 10 & Commelina benghalensis $\mathrm{L}$. & Commelinaceae & + & + & - \\
\hline 11 & Cynodon dactylon (L.) Pers. & Poaceae & - & + & + \\
\hline 12 & $\begin{array}{l}\text { Fimbristylis aestivalis (Retz.) } \\
\text { Vahl. }\end{array}$ & Cyperaceae & + & + & + \\
\hline 13 & Glinus lotoides $L$. & Molluginaceae & + & + & + \\
\hline 14 & Hydrilla verticillata (L.f.) Royle. & Hydrocharitaceae & - & + & - \\
\hline 15 & Ipomoea aquatica Forsk. & Convolvulaceae & + & - & - \\
\hline 16 & Ipomoea carnea Jacq. & Convolvulaceae & + & + & + \\
\hline 17 & Lantana indica $R o x b$ & Verbenaceae & - & - & + \\
\hline 18 & Lemna minor $L$. & Lemnaceae & + & - & - \\
\hline 19 & Nymphaea pubescens Willd. & Nympheaceae & + & + & - \\
\hline 20 & $\begin{array}{l}\text { Nymphoides cristatum (Roxb.) } \\
\text { O. Ktze. }\end{array}$ & Gentianaceae & - & + & - \\
\hline 21 & Prosopis juliflora (Sw.) DC. & Fabaceae & - & + & + \\
\hline 22 & Typha angustifolia $L$ & Typhaceae & + & + & - \\
\hline 23 & Vallisneria spiralis $L$. & Hydrocharitaceae & - & - & + \\
\hline 24 & Vernonia cinerea (L.) Less. & Asteraceae & + & + & + \\
\hline 25 & Wolffia microscopica (Griff.) & Lemnaceae & - & + & + \\
\hline
\end{tabular}




\section{IV.CONCLUSION}

Pond 1 is rich with the species, when compared to other ponds. But in Pond 3 the diversity is comparatively less. Pond 3 is a pond which is used for agricultural purposes and therefore seasonal cleaning is there. Most of the water quality parameters including water $\mathrm{pH}$, Alkalinity, Phosphate Phosphorus, Nitrate-Nitrogen, were highest in P-1 and lowest value of $\mathrm{DO}$ was also recorded in $\mathrm{P}-1$. The health status of $\mathrm{P}-1$ is significantly inferior, the ecological condition of $\mathrm{P}-2$ is better than $\mathrm{P}-1$.

A total of 25 plant species were recorded, 19 families having 24 genera were observed. Among them total 5 families belong to class Monocotyledonae and total 14 families belong to class Diocotyledonae. Among this, Ipomea carnea is dominant species, while other marshy plant species were subdominant.

In this research, it is found that all the ponds have distribution of the hydrophytes and marshy plants. Pond 1 is rich with the species, when compared to other ponds. But in Pond 3 the diversity is comparatively less. Pond 3 is a pond which is used for agricultural purposes and therefore seasonal cleaning is there. Also, the farmers of nearby land impose restrictions over misuse of pond, therefore they remain comparatively clean. This may be the reason for the less diversity in the pond. A regular record of aquatic plants in ponds should therefore be maintained in order to get an insight into the regional diversity as well as for initiating future conservation and management for the proper health and functioning of pond ecosystems.

\section{REFERENCES}

[1]. Ackleson, S. G. (2003). Light in Shallow Waters: A Brief Research Review. Limnology and Oceanography. 48(1): 323-328.
[2]. Ambasht, R. S. and Ambasht, N. K. (1998). Ecology of Indian Wetlands [In:Ecology of Wetlands and Associated Systems; Ed. Majumdar, S. K.; Miller, E. W. and Brenner, F. J. Pennsylvania Academy of Science; Easton; pp. 104-116.

[3]. Barot, C. and Patel, V. (2014). Comparative Study of Seasonal Variation in Physicochemical Properties of Selected Wetlands of Mehsana Districts, North Gujarat. Indian Journal of Applied Research. 4(7): 44-47.

[4]. Ozesmi, S. L. and M. E., Bauer. (2002). Satellite remote sensing of wetlands. Wetlands Ecology and Management. 10: 381-402.

[5]. Shinde, S.E., Pathan, T.S., Raut, K.S., Sonawane, D.L.(2011). Studies on physico-chemical parameters and correlation coefficient of Harsool-savangi Dam, District Aurangabad, India. Middle-East Journal of Scientific Research. 8(3): 544-554.

\section{Cite this article as :}

Madhavi Singh, Bharat Maitreya, "Study of aquatic flora of selected ponds of Gandhinagar, Gujarat", International Journal of Scientific Research in Science and Technology (IJSRST), Online ISSN : 2395-602X, Print ISSN : 2395-6011, Volume 8 Issue 3, pp. 48-51, May-June 2021. Available at doi $\quad$ : https://doi.org/10.32628/IJSRST218313

Journal URL : https://ijsrst.com/IJSRST218313 